\title{
A contemporaneidade em Budapeste
}

\author{
The contemporaneity in Budapeste
}

\author{
Natalia Aparecida Bisio de Araujo ${ }^{1}$
}

Mestre em Estudos Literários do Programa de Pósgraduação da Universidade Estadual Paulista "Júlio e Licenciatura plena em Letras, com habilitação em Português e Francês pela mesma instituição. E-mail: natalia-bisio@hotmail.com
RESUMO: 0 presente artigo tem como objetivo a análise da obra Budapeste, de Chico Buarque, a fim de se refletir como o texto é representativo do atual contexto literário brasileiro. Segundo estudiosos, a influência dos meios de comunicação promoveu a espetacularização e a superexposição do real, de modo que a literatura encarou a demanda do mercado, o gosto dos leitores e a ânsia de captar o contemporâneo. Porém, é possível destacar uma procura em se exprimir a realidade de nosso mundo atual com uma expressão diferente daquela esvaziada pela indústria do realismo midiático. Para isso, a linguagem literária tornou-se o grande diferencial, de modo que o efeito estético ganhou força e buscou envolver atrair ao leitor afetivamente na realidade da narrativa. Observando-se esses traços, este trabalho analisará como Chico Buarque conectou Budapeste à realidade de seu tempo, criou uma expressão artística e estética apreciável e, ao mesmo tempo, preocupou-se em chamar a atenção do público e inserir-se no mercado.

PALAVRAS-CHAVE: Budapeste; Literatura contemporânea; Realidade; Mercado.

ABSTRACT: The article aims to analyze the work Budapeste by Chico Buarque, in order to reflect how the novel represents the current Brazilian literary context. According to scholars, the influence of the media promoted the spectacle and overexposure of the real, so that the literature faced the market demand, the taste of the readers and the urge to capture the contemporary. However, it is possible to highlight a search to express the reality of our world today with a different expression of that emptied by the mediatic realism industry. For this, the literary language became the big difference, so that the aesthetic effect gained strength and sought to attract the reader involved affectively in the reality of the narrative. Observing these traits, this paper will examine how Chico Buarque connected Budapeste to the reality of his time, created an artistic expression and noticeable aesthetic and at the same time, worried to draw public attention and be part of the market.

KEYwoRDS: Budapeste; Contemporary Literature; Reality; Market. 


\section{A literatura contemporânea brasileira}

\subsection{Apreender o contemporâneo}

que significa a literatura contemporânea?, indaga Schøllhammer (2010) no início de sua obra Fiç̧ão brasileira contemporânea. Em torno da resposta, há certa complexidade, afinal, como caracterizar um período literário que ainda está em pleno desenvolvimento? Além da problemática do trabalho do crítico em descrever a produção de nosso tempo, observa-se a mesma dificuldade em relação ao escritor em lidar com a contemporaneidade, já que não possui, ainda, uma visão completa do tempo presente de modo a representá-lo em suas obras. Assim, também se questionam os escritores: como produzir um texto contemporâneo?

Para Flávio Carneiro (2005), discutir nossa produção atual (a do século XXI) constitui-se num trabalho muito delicado, já que precisamos "ler o contemporâneo dentro do mesmo contemporâneo". Desse modo, "tal empreitada, evidentemente, demanda toda uma nova metodologia de leitura, obrigando o analista - seja ele um historiador ou um crítico - a lidar o tempo todo com a instabilidade, a dúvida" (CARNEIRO, 2005, p. 32).

Em meio à complexidade que envolve a caracterização de nossa produção atual, Schøllhammer (2010) descreve o conceito do "contemporâneo intempestivo", baseando-se nas ideias de outros estudiosos. Segundo essa concepção,

[...] o verdadeiro contemporâneo não é aquele que se identifica com seu tempo, ou que com ele se sintoniza plenamente. 0 contemporâneo é aquele que, graças a uma diferença, uma defasagem ou um anacronismo, é capaz de captar seu tempo e enxergá-lo. Por não se identificar, por sentir-se em desconexão com o presente, cria um ângulo do qual é possível expressá-lo. Assim, a literatura contemporânea não será necessariamente aquela que representa a atualidade, a não ser por uma inadequação, uma estranheza histórica que a faz perceber as zonas marginais e obscuras do presente, que se afastam de sua lógica. Ser contemporâneo, segundo esse raciocínio, é ser capaz de se orientar no escuro e, a partir daí, ter coragem de reconhecer e de se comprometer com um presente com o qual não é possível coincidir (SCHØLLHAMMER, 2010, 9-10).

Os escritores, assim, não têm uma visão completa de seu tempo presente, pois não há um distanciamento histórico para analisá-lo em sua totalidade. A dificuldade de apreensão da contemporaneidade, por sua vez, conjuga-se com a urgência em encontrar meios de com ela se relacionar, “[...] estando ciente, entretanto, da impossibilidade de captá-la na sua especificidade atual, em seu presente" (SCHØLLHAMMER, 2010, p. 10).

É com o desejo de se conectar com o atual, que o crítico de Ficção brasileira contemporânea identifica, na produção literária, uma maneira encontrada pelos escritores para interagir com essa temporalidade de difícil captura: uma demanda de realismo, apreendida como a consciência dessa dificuldade. Não se trata, porém, de um retorno aos moldes da escola realista, com suas técnicas de verossimilhança descritiva e objetividade narrativa, mas de uma tentativa de se trabalhar com a realidade pessoal e coletiva - a memória histórica de nossos tempos.

De acordo com essa busca de tratar do real, Beatriz Rezende, em seu ensaio para a revista Grumo (2007), identifica traços de "presentificação" na literatura contemporânea:

Há, na maioria dos textos, a manifestação de uma urgência, de uma presentificação radical, preocupação obsessiva com o presente que contrasta com um momento anterior, de valorização da história e do passado, quer pela força com que vigeu o romance histórico, quer por manifestações de ufanismo em relação a momentos de construção da identidade nacional (REZENDE, 2007, s.p.).

Essa tendência de presentificação é, desse modo, o desejo de se unir à contemporaneidade e captá-la, contrastando-se com as antigas tendências 
de valorização histórica, conforme descreve acima Beatriz Rezende. É nesse sentido que Schøllhamer afirma que "[...] o presente contemporâneo é a quebra da coluna vertebral da história e já não pode oferecer nem repouso nem conciliação [...]" (SCHØLLHAMMER, 2010, p. 12).

Por outro lado, é preciso dizer que a presentificação ou demanda de realismo não se relaciona com o conceito de inovação, como se pensou no contexto das vanguardas, em que a literatura visava ao olhar do presente como tendência ordenadora do futuro. Trata-se, na verdade, de um empenho em se retratar o presente temporal,

[...] uma preocupação pela criação de sua própria presença, tanto no sentido temporal mais superficial de tornar-se a 'ficção do momento' quanto no sentido mais enfático de impor sua presença performativa. Questiona-se, assim, a eficácia estilística da literatura, seu impacto sobre determinada realidade social e sua relação de responsabilidade ou solidariedade com os problemas sociais e culturais de seu tempo (SCHØLLHAMMER, 2010, p. 13).

O desejo da contemporaneidade de "criar presença" relaciona-se, assim, à intenção de que a obra provoque certo efeito de realidade. O caminho para se atingir tal objetivo, porém, não é aquele da mimese ou da representatividade, mas da aspiração de imprimir a realidade social e cultural na literatura. Segundo Schøllhammer, trata-se "[...] de um tipo de realismo que conjuga as ambições de ser 'referencial', sem necessariamente ser representativo, e ser, simultaneamente, 'engajado', sem necessariamente subscrever nenhum programa político [...]” (SCHØLLHAMMER, 2010, p. 54).

A fim de inscrever-se em seu tempo, a literatura contemporânea procurou "reinventar o realismo", segundo Schøllhammer (2010), com a responsabilidade de se religar com os problemas sociais e culturais, sem deixar de lado a dimensão pessoal e íntima. Não significa somente ser engajado ou intimista, mas relacionar-se com o real e o presente, de forma a nos imprimir na literatura. Trata-se de evidenciar o que é estar incluso no mundo atual. Por isso, os caminhos do "realismo" social e da experiência subjetiva se entrelaçam e produzem o efeito de "presença" da literatura na contemporaneidade.

\subsection{As tendências contemporâneas}

Compreendendo o anseio de a literatura contemporânea subscrever-se em seu tempo, "criar presença" e surtir efeito de realidade, é preciso refletir os meios pelos quais esse processo tem se estabelecido. Embora a crítica identifique várias tendências na produção atual, nenhuma delas deixa de se relacionar ao desejo de captar o tempo presente.

Flávio Carneiro, por exemplo, afirma que "[...] o traço mais marcante da prosa brasileira deste início de milênio [...] é o da convivência pacífica dos mais diversos estilos" (CARNEIRO, 2005, p. 33). De fato, como também explica o crítico, nunca houve um período literário e artístico completamente homogêneo. Mas o que chama a atenção em nosso cenário atual é a "[...] ausência do embate entre forças conflitantes" (CARNEIRO, 2005, p. 33).

Com o convívio de vários estilos, segundo Schøllhammer (2010), “[...] os novos realistas querem provocar efeito de realidade por outros meios" (SCHØLLHAMMER, 2010, p. 54). Assim, observam-se as tendências que a literatura contemporânea gerou a fim de criar aquele "efeito de realidade", refletindo nosso tempo presente.

O século XXI vivencia um momento ímpar da história mundial. Depois da invenção e revolução das máquinas, na primeira metade do século $\mathrm{XX}$, temos hoje o alcance das novas tecnologias a um grande número de pessoas, que podem ter em suas casas aparelhos como televisão, rádio, telefone, computadores, eletrodomésticos, dentre outros. Além disso, o aprofundamento do processo de globalização, potencializado, sobretudo, 
pela Revolução Digital, nos possibilita a conexão instantânea com qualquer lugar do planeta. Com os smartphones, os tablets, e os vários tipos de conexão em redes de internet, o indivíduo contemporâneo vive conectado com o mundo e pode visitar os perfis online de seus amigos virtuais. As notícias dos quatro cantos do planeta circulam em tempo real e o serviço jornalístico nos mostra os mínimos detalhes da vida das grandes celebridades. Há programas como os reality shows, programas de auditório, entrevista e outras formas em que o sujeito, presente na tela, está disponível para milhares de expectadores. Além disso, há uma grande espetacularização dos acontecimentos traumáticos e a valorização do choque e do escândalo. Todo esse cenário midiático contribui para o que Schøllhammer (2010) chama de uma grande "demanda de realidade". E o cenário literário não enfrenta uma situação distinta.

O interesse da sociedade contemporânea pelo real e pela vida privada se traduziu, no mercado editorial, na propagação de biografias, diários, reportagens históricas, cartas, relatos de viagens, confissões, memórias, revelações de paparazzi, autobiografias e autoajuda (SCHØLLHAMMER, 2010, p. 56). 0 apreço dos leitores por essas obras revela a grande influência dos meios de comunicação, que incitam a superexposição da realidade. Assim, vê-se a tentativa do mercado editorial em atingir o público do mesmo modo como a mídia os atraiu. Sobre esse assunto, Flávio Carneiro (2005) explica que surge, no século XXI, [...] uma literatura antenada com o mercado, ou seja, uma literatura que não apenas se utiliza dos recursos linguísticos da mídia como também se interessa em atingir o mesmo público almejado por ela (CARNEIRO, 2005, p. 24).

Em contrapartida, o escritor brasileiro, incumbido de tratar da realidade contemporânea de seu país, enfrenta a dificuldade de fazê-lo de uma forma diferente daquela da espetacularização midiática do real. Schøllhammer (2010) observa uma tentativa dos escritores em retratar a realidade, segundo a demanda de seu tempo, mas de modo em que a linguagem literária seja o grande diferencial, em que o efeito estético ganhe força:

Essa procura por um novo tipo de realismo na literatura é movida, hoje, pelo desejo de realizar o aspecto performático e transformador da linguagem e da expressão artística, privilegiando o efeito afetivo e sensível em detrimento da questão representativa. Enquanto aquele realismo engajado estava solidamente arraigado no compromisso representativo da situação sociopolítica do país, as novas formas passam necessariamente por um questionamento das possibilidades representativas num contexto cultural predominantemente midiático. [...] a procura por novas formas de experiência estética se une à preocupação com o compromisso de testemunhar e denunciar os aspectos inumanos da realidade brasileira contemporânea. É claro que tal tendência procura demarcar seu espaço dentro de uma "sede" geral de "realidade", que, com facilidade, se verifica igualmente nos grandes meios de comunicação. Numa situação cultural em que os meios de comunicação nos superexpõem a "realidade" [...], as artes e a literatura deparam-se com o desafio de encontrar outra expressão de realidade não apropriada e esvaziada pela indústria do realismo midiático (SCHØLLHAMMER, 2010, p. 57).

Compromissado com a inovação das formas de expressão e das técnicas da escrita, esse realismo acaba por diferenciar-se da descrição representativa do real, feita de modo chocante e apelativa pela mídia, e acaba, também, por atrair o leitor, que, com o efeito estético da leitura, é envolvido afetivamente na realidade da narrativa. E não é trabalhoso encontrar vários exemplos como esse na produção brasileira deste século. Cinzas do norte, de Miltom Hatoum, vencedor do Prêmio Jabuti de melhor romance (2006), reflete muito essa tendência. Com a história complicada de vários relacionamentos - entre dois amigos, dois irmãos, dois amantes, pai e filho, marido e mulher -, a obra se fundamenta num trabalho intricando da expressão romanesca, envolvendo as perspectivas e as diferentes versões de cada uma das personagens, por meio da inserção de suas cartas, seus diálogos e a visão do narrador-personagem. 0 leitor, aflito, folheia as páginas ansiando 
desvendar o enigma dessas vidas. Porém, por trás dessa trama envolvente, há a contextualização da sociedade amazônica, denunciando seus conflitos e suas mazelas. A obra, assim, não deixa de fazer um retrato da realidade vivida pelo povo amazônico.

O impacto da midiatização na literatura contemporânea também se mostrou em outras tendências - e não somente por meio daquela "demanda de realidade". É preciso considerar que a midiatização contribuiu para revitalizar as formas literárias. Nossa cultura dos blogs, do cinema, do jornalismo e da TV, possibilitou a quebra de fronteiras do gênero romance e a inserção de outros gêneros no projeto literário das obras. Schøllhammer (2010) também comenta esse fenômeno e explica que a midiatização da literatura refere-se

[...] a diferentes momentos de produção textual numa nova cadeia de produção em que o livro deixou de ser o produto final e apenas representa uma etapa provisória de um desdobramento de significantes em novos formatos mais voláteis e porosos da mútua penetração dos diferentes níveis (SCHØLLHAMMER, 2010, p. 62, 63).

Assim, contemporaneamente, é muito comum perceber textos que inserem recursos da escrita não literária, como o discurso jornalístico, teatral, cinematográfico ou de outros gêneros. Além disso, a categoria "romance" é desestabilizada pela inserção de formas breves, como a crônica e o conto, e a adaptação de uma linguagem curta e fragmentária como expressão da urgência em se falar do real. Nesse caso, há também obras que inserem diretamente materiais e experiências da realidade. Outro traço é a adaptação de obras literárias para outros gêneros midiáticos, como o cinema, reflexo sintomático da união da literatura com a mídia e a demanda do mercado. Um exemplo ainda mais extremo é a produção de romances que já preveem sua transposição para o cinema ou para o teatro.
O último grande exemplo de algumas dessas características é $O$ irmão alemão, de Chico Buarque, obra que trabalha artisticamente com elementos da realidade, incluindo personagens e acontecimentos reais que envolvem a própria vida do autor, o que intrigou a crítica e os leitores - afinal, "até que ponto é verdadeira, até que ponto é falsa a história do irmão alemão de Chico?" (CASTELLO, 2014, s.p.). O último romance de Chico Buarque também remete a outra forte tendência da literatura contemporânea: a autoficção. $\mathrm{O}$ termo designa, grosso modo, as obras que apresentam traços biográficos do escritor, trabalhando-os artisticamente. Trata-se, assim, de uma ficção que se apodera da experiência de vida. Sobre essa tendência, Schøllhammer (2010) a caracteriza como uma revalorização da

[...] experiência pessoal e sensível como filtro de compreensão do real Nesse mesmo movimento, são revalorizadas as estratégias autobiográficas, talvez como recursos de acesso mais autêntico ao real em meio a uma realidade em que as explicações e representações estejam sob forte suspeita (SCHøLLHAMMER, 2010, p. 107).

"O real é rendido pela escrita", de modo que se dilui a velha dicotomia entre a ficção e realidade. A ficcionalização das experiências pessoais coloca no centro do real o próprio sujeito, porém, o que apreendemos é, na verdade, uma encenação dele mesmo. Assim, semeia-se a dúvida a respeito da veracidade dos fatos narrados.

Além disso, é preciso dizer que a autoficção também é um recurso que reflete àquela demanda de realidade, ligada à descrição do novo realismo descrito por Schøllhammer (2010). Nesse caso, “[...] o 'eu’ aqui é recuperado pela ficção como parte desse real, como lugar de traumas e cicatrizes que se convertem em índices do real" (SCHØLLHAMMER, 2010, p. 109).

No contexto atual da cultura e comunicação de massa, essa encenação performática do "eu" remete ao cenário da espetacularização midiática do 
real. Com o interesse da sociedade atual em conhecer a vida privada, frente à superexposição da realidade efetuada pelas mídias, o recurso da autoficção transforma-se em um modo de atingir o gosto do público, interessado em revelar a intimidade do escritor. Porém, não se resume a isso. Como a figura do autor também faz parte do espetáculo midiático, o trabalho ficcional com os dados biográficos coloca em xeque a expectativa do público em reconhecer na obra a figura do escritor. Segundo Schøllhammer,

Ao desestabilizar as sólidas posições de autor, personagem e leitor, essa espécie de estratégia performativa consegue relativizar a realidade referida pela narrativa na construção de um perspectivismo complexo que concretiza a situação de exibição e observação, ao questionar a realidade representada tal como aparenta espontaneamente. 0 autor procura, em outras palavras, dar realidade à situação de observação, incluindo o leitor na exposição direta dos fatos, ao mesmo tempo que questiona o perspectivismo cenográfico ao qual a observação está submetida e que afeta a veracidade e confiabilidade tanto do testemunho do autor, do narrador, do personagem quanto do leitor (SCHøLLHAMMER, 2010, p. 111, 112).

A autoficção não se trata de uma mera descrição representativa e espetacularizada do escritor como personalidade do contexto midiático, mas de um trabalho estético com a figura íntima do autor, em que a ótica do público sob sua imagem é trabalhada, transformada e, muitas vezes, questionada. Assim, a representação do real é debatida por meio da perspectiva tanto do próprio escritor, quanto do leitor, já que essa realidade está permeada pela subjetividade de quem olha.

\section{Budapeste}

\subsection{0 enredo e as personagens}

O romance Budapeste relata a história José Costa, uma espécie de autor anônimo que faz textos sob encomenda, como monografias, trabalhos escolares, cartas de amor, autobiografias romanceadas e discursos políticos, culminando no best-seller $O$ ginógrafo, escrito por Costa a pedido do alemão Kaspar Krabbe. O protagonista tem grande prestígio nessa função de ghostwritter e possui uma empresa em sociedade com Álvaro Cunha chamada Cunha \& Costa Agência Cultural. É casado com Vanda, uma jornalista que vive dando conselhos ao marido, pois o considera explorado pelo sócio. o casamento tem perturbações constantes e entre o casal a frieza e o distanciamento são explícitos.

Quanto a sua profissão, a personagem revela-se tomada por uma espécie de "volúpia da obscuridade", pois José Costa aprecia o fato de ser um escritor anônimo, "um profissional-serviçal da imagem alheia". Nas palavras de José Miguel Wisnik (2003):

Zé-ninguém e gênio pelas costas, [o protagonista] saboreia o sucesso dos seus textos publicados sob o nome de outrem com o prazer e o ciúme avesso de se sentir a um só tempo autor e outro, excluído e intrusivo, não bafejado pela fama, mas como que privilegiado pelo dom de uma ciência oculta (WISNIK, 2003, s.p.).

A vida de Costa é surpreendida quando, em uma escala forçada de avião, o escritor vai parar em Budapeste. Lá, ele se "enfeitiça" pelo húngaro e, tomado por essa obsessão de dominar a língua a todo custo, envolve-se com Kriska. A imersão do protagonista em outro idioma representa sua inserção em outra identidade: de José Costa passa a ser Zsoze Kósta. A aprendizagem do húngaro torn-se-se muito importante para a personagem, que é dotada de "um ouvido infantil que pega e larga as línguas com facilidade" (BUARQUE, 2003, p.48). Portanto, o protagonista representa um homem que vive das palavras e que, por meio delas, desdobra-se em seu duplo: “[...] a personagem se moverá entre dois idiomas, o seu e o que passa a desafiá-lo, entre duas mulheres e entre duas cidades" (RESENDE, 2003, s.p.). 
Do mesmo modo, Costa - um ghost-writter, que fez diversos escritos sob encomenda e que nunca levou mérito pela autoria deles - desdobrase em um escritor famoso por sua autoficção Budapest, que, na verdade, não escreveu. Assim, como afirma Veríssimo (2003), entende-se que o livro Budapeste, ao ter na capa a indicação de um autor, já nos revela que o escritor na verdade é outro, e não aquele ali denominado. Dessa forma, por ironia da profissão do anonimato, José Costa é fadado a ter mérito pela publicação de um único livro, o qual ele não escreveu:

Enquanto isso o canalha escrevia o livro. Falsificava meu vocabulário, meus pensamentos e devaneios, o canalha inventava meu romance autobiográfico. E a exemplo da minha caligrafia forjada em seu manuscrito, a história por ele imaginada, de tão semelhante à minha, às vezes me parecia mais autêntica do que se eu próprio a tivesse escrito [...] 0 autor do meu livro não sou eu (BUARQUE, 2003, p. 169-170).

A respeito das mulheres que fazem parte da vida do escritor anônimo e do relacionamento que ele tem com ambas, podemos ponderar algumas diferenciações. Com Vanda, sua mulher no Brasil, Costa não conseguia expressar-se: "mimando cada palavra que punha no papel, não me sobravam boas palavras para ela” (BUARQUE, 2003, p. 160).Já com Kriska, em Budapeste, ele precisa encontrar as melhores palavras para conseguir vencer o silêncio desse relacionamento: "duas pessoas não se equilibram muito tempo lado a lado, cada qual com seu silêncio” (BUARQUE, 2003, p.150).

Como se pode perceber, a grande incógnita desse narrador-protagonista é o universo das mulheres, sendo que, essas duas personagens, Kriska e Vanda, são muito diferentes: Vanda, uma telejornalista carioca em ascensão, que gostava de expor-se pelas mídias; e Kriska que representava um corpo de palavras nunca inteiramente revelado. Segundo Wisnik, essas diferenças são muito importantes para compor o universo do romance e, portanto, tais personagens complementam-se e acabam por unir-se: "as duas formam uma só" (2003, s.p.).

\subsection{Recepção da crítica}

Como nosso contexto atual foi transformado pelas novas tecnologias e pela pressão do mercado editorial, as críticas literárias circulam em vários meios de comunicação e, muitas vezes, ditam as regras e o gosto do mercado - embora se possa perceber com grande frequência que o discurso crítico foi parcial em sua análise das obras. Por isso, tratar da recepção da crítica é muito importante para se compreender em que condições os textos circularam pelo mercado. 0 romance Budapeste, publicado em 2003, de modo geral, foi bem recebido pela crítica, fato que reflete seu sucesso.

O livro de Chico Buarque ganhou o Prêmio Jabuti de 2004 na categoria "livro do ano de ficção" e o terceiro lugar na categoria de melhor romance. A obra também recebeu o Prêmio Passo Fundo Zaffari \& Bourbon de Literatura, na quarta edição, em 2005, como o melhor romance em língua portuguesa publicado entre 2003 e 2004.

Budapeste recebeu elogios de muitas figuras bastante reconhecidas no cenário literário e artístico. Em uma resenha no jornal $O$ Globo, na edição do dia 14 de setembro de 2003, Caetano Veloso considera o romance como "[...] o mais belo dos três livros da maturidade de Chico, [...] um labirinto de espelhos que afinal se resolve, não na trama, mas nas palavras, como poemas" (VELOSO, 2003, s.p.).

Na mesma data e no mesmo jornal em que publica Caetano Veloso, Luís Fernando Veríssimo associa o estilo do livro e a concepção de escritor inclusa na obra às características do fantasma, em uma analogia ao ghost-writter. Também no dia 14 de setembro, em que borbulhavam comentários do livro de Chico Buarque, José Saramago publica no jornal Folha de São Paulo uma observação semelhante à de Veríssimo, a ideia de que o livro circula em uma 
atmosfera de "fantasmagoria e ficção". O escritor português faz um grande elogio a Budapeste, que chega a ser publicado na contracapa da edição da Companhia das letras: "Chico Buarque ousou muito, escreveu cruzando um abismo sobre um arame e chegou ao outro lado. Ao lado onde se encontram os trabalhos executados com mestria, o da linguagem, o da construção narrativa, o do simples fazer. Não creio enganar-me dizendo que algo novo aconteceu no Brasil com este livro" (SARAMAGO, 2003, s.p.).

O livro ainda recebeu crítica positiva do especialista em literatura e professor da Universidade de São Paulo, José Miguel Soares Wisnik, que; ao analisar o romance de Chico, baseando-se na temática do duplo, afirma que "Budapeste, no exato momento em que termina, transforma-se em poesia. 0 romance esconde a versão oculta de si mesmo, e se soletra todo, num flash extremo, como uma língua-música, que se desse de uma vez, por inteiro" (WISNIK, 2003, s.p.).

O cenário crítico da época de publicação da obra continuou com a mesma expressão dos elogios alguns anos mais tarde. Martha LaFollette Miller, no ensaio para a revista Eutomia (2009), afirma que dentre os quatro romances anteriores de Chico Buarque, Budapeste foi o que recebeu uma recepção mais favorável por parte da crítica, devido, sobretudo, a sua sofisticação e complexidade. Segundo a estudiosa, o romance ganhou destaque em meio ao cenário acadêmico, que ressaltou na obra aspectos meta-literários e a forma pela qual o texto problematiza questões de identidade e autoria.

\subsection{0 duplo}

Pode-se dizer que Budapeste é uma narrativa do duplo, uma história que envolve duas línguas, dois países, duas cidades, duas mulheres e a figura dúbia de um personagem escritor. Até mesmo o título envolve essa duplicidade: Budapeste é a fusão de duas cidades, Buda e Peste, separadas pelo rio Danúbio.
Não só na literatura, mas também em outras artes, na mitologia ou na história, o duplo pode ser tematizado. Geralmente a simbologia da duplicidade está intimamente ligada à identidade do ser humano, que possui uma personalidade duplicada, lotada de problemas e enigmas. No trabalho de criação literária, o próprio escritor é divido: ele tem sua identidade própria, mas, em suas obras, torna-se outro, reinventa-se, cria uma "pessoa de papel", e escreve por meio desse "outro".

A questão da alteração de identidade e da duplicidade é focada de maneira muito sofisticada em Budapeste, na figura de José Costa, um escritor que vive entre a fama e o anonimato. Trata-se de um ghost-writter, que assiste ao sucesso de suas obras sem gozá-lo, já que elas são publicadas com o nome de outros. É um "ninguém", um desconhecido, mas ao mesmo tempo é um gênio, um escritor "inspirado". Um homem que vive entre o "eu" e o "outro".

Juntamente a essa personalidade dúbia do protagonista, seguem outros contrapontos entre duas realidades da personagem: o Rio de Janeiro e Budapeste; duas línguas, o português e o húngaro; a parceira brasileira, de pele morena, e a parceira húngara, de pele branca; dois filhos problemáticos, Joaquinzinho e Pisti; duas obras de sucesso publicadas com o nome de outro, o Ginógrafo e os Tercetos Secretos.

O espaço caracterizado pela obra já expõe certa duplicidade: “Uma história em dois lugares, o Rio e um anti-Rio, Budapeste" (VERÍSSIMO, 2003, s.p.). O espaço de Budapeste dá continuidade ao tema do duplo presente no romance. 0 protagonista sente-se sempre desencontrado, pois, quando está em Budapeste sente saudades do Brasil e da vida que levava aqui, porém, quando está no Brasil, sente falta de Budapeste, almejando retornar para lá. Portanto, José Costa divide-se entre esses dois espaços, bem como os acontecimentos da diegese.

Budapeste é, como já dito, formada por duas cidades siamesas, Buda e Pest, divididas pelo Danúbio, que as corta em ípsilon. Segundo José Miguel 
Wisnik (2003, s.p.), a capital retratada no romance de Chico Buarque é "arquitetada com matéria de sonho e de realidade, uma cidade que nasce do magma sonoro e significante da língua, um contraponto ao Rio de Janeiro, seu avesso ao mesmo tempo familiar e estranho".

No Rio, o escritor já tem o papel do estranho, do "desconhecido", em sua própria casa: Vanda, com quem é casado, não o trata como marido; o filho não o reconhece como pai. As relações familiares são extremamente precárias. A própria mulher de Costa, no início, ignorava que o marido escrevera o Ginógrafo, livro que tanto admirava e que ganhou fama com a assinatura do escritor alemão.

Fugindo de seus problemas no Rio de Janeiro, o protagonista retorna à Hungria, já movido por uma paixão: aprender a "única língua que o diabo respeita". Nesse espaço, José Costa constrói outra vida, passa a dominar outro idioma, relaciona-se com outra mulher, Kriska, e mantém certo papel de pai com o filho dela. Cria-se uma nova identidade, a de Zsoze Kósta. Têm-se, assim, dois "Josés", o brasileiro e o húngaro.

De um lado, assim, temos a vida do personagem no Brasil e, de outro, a vida na Hungria. A primeira se contrasta com a segunda. Rio é a "cidade maravilhosa", com paisagens encantadoras, porém, nesse ambiente, o personagem não encontra a si mesmo. A cidade também representa o Brasil, seu país natal, com sua língua materna, mas sua identidade brasileira está em conflito. Por isso vai à Budapeste, a cidade "amarela", em busca de "se encontrar". A vontade de aprender o húngaro e chegar a ponto de perder o sotaque estrangeiro representa a necessidade de criar uma nova personalidade, praticamente para escapar daquela do homem carioca. Os anos vividos em Budapeste e o grande esforço do personagem para aprender a língua magiar faz com que ele atinja seu objetivo. José Costa chega ao ponto de, ao retornar ao Brasil, ver seu idioma materno como estrangeiro, estranho:
Ali, por uns segundos tive a sensação de haver desembarcado em país de língua desconhecida [...]. Logo reconheci as palavras brasileiras, mas ainda assim era quase um idioma novo que eu ouvia, não por uma outra gíria mais recente, corruptelas, confusões gramaticais. 0 que me prendia a atenção era mesmo uma nova sonoridade, havia um metabolismo na língua falada que talvez somente os ouvidos desacostumados percebessem (BUARQUE, 2003, p. 155).

E nessas duas personalidades do protagonista, temos o efeito de reflexo. É como se José Costa estivesse frente ao espelho e o que aparece refletido é a figura de Zsoze Kósta. De um lado, o que se observa, é o brasileiro, que mora no Rio, que fala português, casado com Vanda. Do outro lado, do reflexo, é um húngaro, falante da língua magiar, que vive em Budapeste junto com Kriska.

A própria capa do livro interage com a ideia do espelho: o lado de trás pode ser lido como uma reflexão do lado frontal, porém, neste está escrito o nome de Chico Buarque; naquele vem grafado o nome de Zsozé Kósta (cf. ANEXO, Figura 1). Esse aspecto da capa é muito interessante, já que a leitura da obra de Chico Buarque induz à ideia de que Budapeste é o próprio livro que fora escrito por outro e publicado com o nome de Zsozé Kósta, conforme analisaremos posteriormente neste trabalho.

A respeito da autoria do romance, são dignas de nota as considerações feitas por Luis Fernando Veríssimo: "Se o nome de um aparecer na capa de um livro, é prova de que o livro não é dele - é de outro fantasma. José Costa, com o pseudônimo de Chico Buarque, escreve a sua própria história [...]" (2003, s.p.). Nesse emaranhado de autores fantasmas, temos, de um lado, José Costa, um ghost-writter, que fez diversos escritos sob encomenda e que nunca levou mérito pela autoria deles e, de outro lado, temos a misteriosa figura de Sr..., ex-marido de Kriska, também um "escritor fantasma", suposto autor do Budapest assinado com o nome de Zsoze Kósta: 
E ela ainda me dizia que o ex-marido tinha um coração de ouro, se preocupara ao saber por Pisti de seu estado, mandara Pisti assegurar à mãe que não pouparia engenho e recursos para trazer seu homem de volta a Budapeste. Ingênua, Kriska se comovera às lágrimas, pois raros exmaridos sabem ser tão altruístas, e fez com que Pisti transmitisse ao pai seu profundo reconhecimento. Enquanto isso o canalha escrevia o livro. Falsificava meu vocabulário, meus pensamentos e devaneios, o canalha inventava meu romance autobiográfico (BUARQUE, 2003, p. 170).

Nota-se, portanto, o emaranhado autoral construído por meio desse recurso: Budapeste foi escrito por Chico Buarque? Por José Costa? Pelo Sr...? Chico Buarque é pseudônimo de José Costa? O romance foi escrito em húngaro? Em português? O romance constrói-se, portanto, por meio de um

[...] processo de repetições sucessivas que, se não chegam a ser de universos nem de literaturas, sem dúvida o serão, inquietantemente, de autores e de livros. 0 mais desassossegador, porém, é a sensação de vertigem contínua que se apoderará do leitor, que em cada momento saberá onde "estava", mas que em cada momento não sabe onde "está". Sem parecer pretendêlo, cada página do romance expressa uma interpelação "filosófica" e uma provocação "ontológica": o que é, afinal, a realidade? (SARAMAGO, 2003, s.p.).

A fim de sustentar a temática do duplo, o escritor vale-se de alguns recursos estilísticos, como as repetições e o efeito circular dos fatos narrados, como se observa, por exemplo, com a reincidência do trecho final d' $O$ ginógrafo: "E a mulher amada, cujo leite eu já sorvera, me fez beber da água com que havia lavado a blusa" (BUARQUE, 2003, p. 40). O mesmo excerto encerra o romance de Chico Buarque (2003, p. 174), o que mais uma vez sustenta a rede de obscuridades e de espelhamento presentes na obra. Outra repetição de acontecimentos já se inicia pela capa, que contém um excerto da obra: "Fui dar em Budapeste graças a um pouso imprevisto, quando voava de Istambul a Frankfurt, com conexão para o Rio [...]” (BUARQUE, 2003, p. 6).
Algumas experiências vividas pelo ghost-writter também são repetidas várias vezes ao longo do romance como, por exemplo, o episódio do dia de Ano-Novo em que Costa acaba confessando a autoria d'o ginógrafo para sua esposa Vanda. A visão de Kriska nua, com sua brancura - "Branca, branca, branca, eu dizia, bela, bela, bela, era pobre o meu vocabulário" (BUARQUE, 2003, p. 45) - também reincide pelo romance.

Outra recorrência expressiva é o excerto do início da obra - "Devia ser proibido debochar de quem se aventura em língua estrangeira" (BUARQUE, 2003, p.5) - que aparece novamente no final do romance enquanto José Costa está lendo o livro Budapest para Kriska. Percebe-se que esse recurso confere circularidade ao texto, construindo uma espécie de ciclo em que a história termina do mesmo modo que começa. A repetição também corrobora para fazer o leitor crer que Budapest, que está nas mãos de José Costa no final da história é, de fato, o mesmo romance que ele está lendo, Budapeste, de Chico Buarque. Enquanto Costa lia Budapest, os fatos ali narrados aconteciam concomitantemente à leitura, ocorrência que confirma que a obra do autor brasileiro é exatamente a mesma que a ficcional, do escritor húngaro: "E no instante seguinte se encabulou, porque agora eu lia o livro ao mesmo tempo que o livro acontecia” (BUDAPESTE, 2003, p. 173).

Quanto à pontuação, notamos a peculiaridade de que não há utilização de travessões para o anúncio das falas, como podemos perceber no trecho "[...] telefonei da rua e disse: aí estou chegando quase" (BUARQUE, 2003 , p. 5), recurso que confere maior movimentação à narrativa, tornando-a mais corrente. O que mais chama atenção no romance de Chico Buarque, quando comparado aos enredos de seus romances anteriores, é "linguagem mais palatável" (CHAGAS, 2003, s.p.), sedutora, capaz de envolver completamente o leitor e aprisioná-lo na armadilha contida nas entrelinhas: o que é, de fato, a realidade? 


\subsection{A metalinguagem}

O livro de Chico Buarque, com a história de um ghost-writter, entra em uma questão muito interessante da literatura: a identidade, a autoria e a alteração da personalidade do escritor. "O poeta é um fingidor", como diz o poema "Autopsicografia", de Fernando Pessoa. Não só o poeta, mas também todo o prosador é um "fingidor", no sentido de que não expressa em sua obra uma mera transcrição do real, mas algo que vem da realidade e é trabalhado com a razão, transformado artisticamente.

0 autor tem, ainda, a possibilidade de recriar o mundo de maneira ficcional. Desta forma, ele pode expressar pensamentos, ideias e ações de quem quiser e da forma como quer. Consegue também modificar essa realidade por meio da função da linguagem narrativa. Com isso, o escritor não depende da realidade e é capaz de ultrapassar seus limites, mudar os conceitos do tempo, do espaço e até mesmo da lógica da sociedade real. Para isso, no trabalho artístico, o escritor não imprime à obra sua identidade, mas falsifica-a, criando uma "persona de papel".

José Costa, o protagonista de Budapeste, vive ao extremo esse papel do escritor que altera sua identidade. Ele leva isso às consequências de escrever suas obras e entregá-las a outros. Além de falsificar sua identidade na construção literária, adultera também a própria autoria de seus livros. É um ghost-writter, escreve coisas para outros e seu nome nunca aparece nos livros.

Nesse caso, em Budapeste, temos um jogo interessante entre identidade e autoria, como também do escritor que falsifica sua identidade. Chico Buarque escreve a história de José Costa, uma "persona de papel", uma criação. 0 livro é narrado em primeira pessoa, mas sabe-se que não se trata do "eu" de Chico, mas o "eu" de seu personagem. De outro lado, tem-se um José Costa, o narrador, que escreve sua própria história e a "publica" com o pseudônimo de Chico Buarque. Ou o contrário: Chico Buarque que, ultrapassando sua própria identidade, se faz outro, o José Costa.

Além disso, essa ideia da identidade e da autoria chega a certo ponto cômico na obra: José Costa sempre escreveu livros para outros, sem nunca ser reconhecido por suas obras. Porém, surge Budapest, romance que trata de suas próprias memórias, mas que não foi escrito por ele. Um livro de Costa, escrito por um fantasma, um ghost-writter. A personagem tentou negar o a autoria da obra, porém, sem êxito: "O autor do livro não sou eu, emendei, levando a multidão às gargalhadas" (BUARQUE, 2003, p. 170). 0 jogo de reflexos entre as identidades de Chico Buarque e de José Costa conduz à ideia de que o próprio Chico teria sido o ghost-writter produtor de Budapest.

Com isso, em Budapeste, pode-se destacar o tema da metalinguagem, uma obra que reflete a própria criação literária, na qual o escritor é aquele que se inventa como outro e que escreve, por meio de outrem, a própria obra. O romance de Chico Buarque, assim, promove uma reflexão do papel da literatura e do escritor, na qual quem escreve sempre se estabelecerá no lugar de outro.

\section{A contemporaneidade de Budapeste}

Pode-se perceber que o estilo apurado de Budapeste se destaca ainda mais que nos romances anteriores de Chico Buarque, possuindo marcas fortes de alucinação, estranhamento, com pitadas de humor e de erotismo. Sua prosa vale-se de precisão descritiva, inserção de diálogo no texto do próprio narrador, retratos esmerados da conduta feminina, toque de ironia sobre as vaidades presente no mundo literário, bem como no tratar das relações domésticas, dentre outros elementos (SANTANA, 2003, s.p.).

Com tais características, Budapeste insere-se em várias tendências da contemporaneidade. Primeiramente, é possível identificar aquele desejo 
da literatura atual em "criar presença", ou seja, provocar certo efeito de realidade. No modelo de focalização e de narração da obra, é possível evidenciar esses aspectos por meio de um narrador autodiegético - que narra os acontecimentos que lhe são próprios - e a focalização interna e fixa ${ }^{1}$ - que parte da interioridade do protagonista -; da narração com ares de realidade que leva o leitor a ser convencido pelo narrador, já que os detalhes do enredo lhe são expostos em "primeira mão", vindos da própria personagem. Apesar de não se tratar de uma autoficção, uma grande tendência contemporânea, Budapeste oferece um vislumbre da encenação performática de um "eu", permeada por sua subjetividade, na tentativa de fisgar o leitor em seu intrigante enredo.

Por meio do efeito da focalização interna e fixa e da narração autodiegética, a visão de José Costa apresenta fatos parciais, além de que também ficam evidentes suas suposições, dúvidas e questionamentos, como podemos notar na seguinte passagem do romance, em que José Costa supõe a traição de sua esposa Vanda com o alemão Kaspar Krabbe, suposto autor d'O Ginógrafo:

Seria um contra-senso eu querer mal a ele [Kaspar Krabbe] por ter feito o que eu faria em seu lugar, como pedir para ela tirar a roupa de baixo antes da roupa de cima e tal e coisa. Ao deixá-la em casa de madrugada, se fosse ele, eu também pegaria no porta-luvas um exemplar de $O$ ginógrafo, que apoiaria nas coxas dela no escurinho do carro e dedicaria para Wanda, lembrança do nosso tête-à-tête, encantado, K.K., mesmo sabendo que ela leria apenas a última página no elevador (BUARQUE, 2003, p. 83).

Dessa forma, como fica claro na citação, o narrador-protagonista supõe o possível envolvimento de Vanda com Kaspar Krabbe, porém, o leitor não consegue comprovar a veracidades desse fato. E não é só na narração autodiegética que verificamos a arquitetura de suposições e obscuridades:

\footnotetext{
${ }^{1}$ Segundo as categorias narrativas propostas por Gérard Genette (s/d).
}

o duplo e o jogo de reflexos entre identidade e autoria da obra também levam a outros enigmas. Instaura-se uma teia de pressuposições capaz de fisgar o leitor de Budapeste a tentar deduzir as verdades da trama. Eis uma das estratégias da literatura contemporânea usadas para atrair a atenção do público por meio do trabalho estético.

Além do recurso da focalização, a obra cria sua "presença" na contemporaneidade ao discutir em suas entrelinhas o contexto atual no qual se insere a obra literária e seu escritor. Com a espetacularização provida pelo advento das mídias, a literatura sucumbiu à pressão do mercado editorial. As obras tornaram-se parte do espetáculo, produtos a serem consumidos pelo mercado. Do mesmo modo, o autor também participa da exibição midiática, como parte do espetáculo. Vê-se em Budapeste uma reflexão apurada desse cenário, em que o artístico deixou de ser o centro e a literatura banalizou-se. Segundo Wisnik (2003), Budapeste mostra-se como uma verdadeira e imensa anedota dotada de "reflexão aguda e sibilina sobre o papel da literatura e o papel do literato" (WISNIK, 2003, s.p.).

Como podemos perceber na seguinte passagem a respeito da venda d' $O$ ginágrafo, há uma descrição muito irônica do narrador ao retratar a comercialização dos livros, que se transformaram em objetos banais de consumo.

Além de expostos de longo a longo na vitrine, havia uma pilha deles no balcão. As pessoas entravam, passavam a mão num exemplar e se acertavam no caixa, quando não iam diretamente ao caixa como quem compra cigarros: me vê um Ginógrafo. Outros chegavam, davam uma olhada nas estantes, apuravam o preço dos importados, bordejavam a bancada com os lançamentos recentes, acabavam topando a pilha sobre o balcão; está saindo à beça, dizia o livreiro, ou, até o Natal bate os cem mil, e essa espécie de recomendação era tiro e queda, mais um Ginógrafo embrulhado para presente. Postado no centro da pequena livraria, num pedaço de tarde perdi a conta dos fregueses que saíram com o meu livro. Passavam por mim sem me olhar, esbarravam em mim sem imaginar quem eu fosse, e aquilo me enchia de uma vaidade que havia muito tempo eu não sentia (BUARQUE, 2003, p. 93). 
A ironia em que o narrador reflete sua vaidade em não ser identificado pelos "consumidores" da obra que ele escrevera, contrastada à ostentação em que o alemão Krabbe identificava-se como o verdadeiro autor, questiona diretamente a exposição dos escritores frente à efervescência do consumo dos livros. A vaidade de Costa, mesmo em seu anonimato, revela sua satisfação ao ver o sucesso do livro ao mesmo tempo em que não é reconhecido como seu escritor, ou como parte do espetáculo.

Outra grande ironia é o desaparecimento de $O$ Ginógrafo das estantes da livraria tempos depois:

No entanto, andando pelo comércio de Copacabana, avistei uma livraria com a vitrine coberta de livros cor de mostarda. Aproximei-me, e talvez o reflexo do sol na vidraça faiscasse as cores, pois os livros derivavam para um tom de ocre com letras verdes. Mais um pouco, e já era quase nítido o título $O$ Ginógrafo, em letras góticas lilás nas capas do livro cor de canela. Mas quando cheguei à livraria, o livro era azul-marinho e se chamava $O$ Naufrágio. Entrei, espiei variados volumes expostos nas mesas, só por curiosidade rondei as estantes, dei com o livreiro: O Ginógrafo, me faça o favor. Como disse? O Ginógrafo. 0 senhor deve estar equivocado, aqui temos $O$ Naufrágio, que já vendeu mais de cem mil exemplares. Insisti: $O$ Ginógrafo. Perguntou se era algum livro técnico, nunca ouvira mencionar semelhante nome. Mentira dele, eu me lembrava da sua figura, ele ganhara uma fortuna às custas do meu romance. Acedeu em consultar um computador, indagou se a palavra se escrevia com gê, falou: guia de Gênova... manual de ginástica.., as gira- ...... ginógrafo não consta. 0 senhor por acaso tem o nome do autor? Kaspar Krabbe? Cá, erre, a, bê, bê, é? Krabbe... Krabbe... Kaspar... Kaspar Krabbe também não consta. A editora, por acaso? (BUARQUE, 2003, p. 150).

A literatura, assim, é refém do jogo lucrativo do mercado. O desaparecimento de $O$ Ginógrafo e a atitude do dono da livraria em não reconhecer o romance revelam a a rapidez da circulação das obras literárias nas estantes: ganham sucesso e logo perdem o brilho frente às novas publicações. Não há tempo para uma discussão mais apurada quanto às características artísticas e à qualidade dos livros, mas, esgotados os lucros, as obras precisam desaparecer para dar lugar a outras e, desse modo, reiniciar o processo lucrativo das vendas. Por meio de recursos irônicos, Budapeste questiona esse contexto do mercado editorial. E, para consolidar a ironia à questão da autoria e da figura espetacularizada do autor, depois de ter escrito grandes sucessos de vendas para outros sujeitos, Costa tornase reconhecido por uma obra que não escreveu. Esse sucesso o incomoda extremamente: "Era um enfado, era muito triste, eu poderia baixar as calças no centro da cidade, ninguém se surpreenderia” (BUDAPESTE, 2003, p. 172). Vemos, ironicamente, como o mercado o cerca por todos os lados e o arrasta para a fama, sem sua própria vontade. É manipulado como um boneco, de modo que até mesmo sua fala perante o público já lhe era imposta:

Fui recebido no Parlamento, jantei no Palácio do Arcebispo, na Universidade de Pécs me concederam um título de doutor, que agradeci com um discurso empolado, surgido em meu bolso não sei como. Meus passos se tornaram vagarosos, eu ia aonde me conduziam, eu já sabia o que me esperava, era como se meu livro continuasse a ser escrito. Em palestras, ainda tentava falar de improviso, tinha um ou outro lampejo de espírito, mas meus leitores já os conheciam todos. Eu ideava palavras estrambóticas, frases de trás para diante, um puta que o pariu sem mais nem menos, mas nem bem abria a boca, e na plateia algum exibicionista se me antecipava (BUDAPESTE, 2003, 172).

Assim, frente ao que acontece com Costa, vemos como se "faz um autor", como se cria uma personalidade famosa. Com isso, ironicamente, podemos fazer um paralelo do modo como as leis de mercado e da mídia inseriram-se no contexto literário e transformaram completamente o espaço da produção artística de nossos tempos, banalizando-a e fazendo dela uma parte do espetáculo.

Além disso, é preciso dizer que o retrato dessa realidade do mercado editorial contemporâneo é acompanhado, na obra, por um trabalho estético 
realmente singular. Ao retratar a realidade de seu tempo, a obra não deixa de fazer com que a linguagem literária seja o grande diferencial e que o efeito estético ganhe força. Assim, com o aspecto performático e transformador da linguagem e da expressão artística, Budapeste também privilegia o efeito afetivo e sensível das novas formas, atraindo a atenção dos leitores. Seduzido pela eficácia estilística do romance, estonteado pela sua circularidade, pelo seu processo do duplo e por suas repetições, o leitor é levado até à última página. O livro constrói-se nas incertezas e nas dúvidas, constituindo-se como um romance de "vertigem", como afirma Veríssimo (2003):

O livro do Chico é uma vertigem. Você é sugado pela primeira linha e levado pelo estilo falso-leve, a prosa depurada e a construção engenhosa até sair no fim lamentando que não haja mais, assombrado pelo sortilégio deste mestre de juntar palavras. Literalmente assombrado.

Com essa "construção engenhosa", de estilo e linguagem apurada, cheia de espelhamentos e arquitetada em duplos, o romance elabora-se para dar ênfase ao conflito íntimo vivido pelo protagonista. Enquanto a obra reflete sua circularidade e espelhamento, o leitor, em "vertigem", acompanha o desenrolar do romance entusiasmado. De forma aparentemente despretensiosa, o romance promove uma grande provocação e questionamento da condição da literatura de nossos tempos.

De forma aparentemente despretensiosa, o romance promove uma grande provocação e questionamento da condição da literatura de nossos tempos.

A contemporaneidade de Budapeste, assim, está na constituição de sua presença performativa em seu atual contexto, ao revelar e envolverse com a situação vivida pela literatura atual, em que o artístico tornouse produto comercial. 0 romance provoca um efeito de realidade ao tratar dessa problemática, porém sem ter a pretensão de fazer uma descrição representativa e minuciosa do real. Trata-se, antes de tudo de uma obra compromissada com a inovação das formas de expressão e das técnicas da escrita. Por meio da vertigem e da sedução de seu estilo, Budapeste atrai o seu leitor com um método diferente daquele das mídias, que o faz por meio do choque e da apelação. Apesar de criticar em suas entrelinhas a condição em que estão inseridas a obra literária e a questão da autoria, o romance não deixa de atrair ao público e de se tornar um sucesso no mercado, o qual ele mesmo condena. Afinal, o próprio Chico Buarque é uma grande personalidade perante o público e seu livro também se insere nesse grande comércio que se tornou a literatura.

Nesse sentido, observa-se outro sintoma do contexto contemporâneo: obras literárias que se transformam em outros gêneros. Budapeste foi adaptada para o cinema em 2009, com o título homônimo, em direção de Walter Carvalho. Trata-se do interesse em transpor uma obra de sucesso em meio ao público para outra linguagem artística, porém, também com interesse de atrair expectadores. Vê-se a teia de relações do contexto contemporâneo, em que a literatura relaciona-se com outras artes e gêneros.

É evidente, assim, em Budapeste, o modo como a literatura contemporânea procura relacionar-se com a realidade de seu tempo, criar uma expressão artística e estética apreciável, sem deixar de preocupar-se em atrair ao público e inserir-se no mercado.

\section{Referências}

BUARQUE, Chico. Budapeste. São Paulo: Companhia da Letras, 2003.

CARNEIRO, Flávio. No país do presente - ficção brasileira no início do século XXI. Rio de janeiro: Rocco, 2005.

CASTELLO, José. Crítica: 'O irmão alemão' vai ao limite de uma busca alucinante. O Globo, Rio de Janeiro, 15 nov. 2014. Disponível em: Acesso em: 19 de agosto de 2016.

CHAGAS, Luis. Estilo retocado. [2003]. Disponível em: http://www.chicobuarque.com.br/ critica/crit_budapeste_istoe.htm. Acessado em: 10 ago. 2016. 
GENETTE, Gérard. Discurso na narrativa. Lisboa: Vega, s/d.

RESENDE, Beatriz. Contemporâneos- expressões da ficção brasileira no século XXI. Rio de Janeiro: Casa da palavra, 2008.

RESENDE, Beatriz. Movido pelas palavras. [2003]. Disponível em: http://www. chicobuarque.com.br/critica/crit_budapeste_brasil.htm. Acesso em: 10 ago. 2016.

RESENDE, Beatriz (2007). "Questões da ficção brasileira do século XXI". Revista Grumo, n. 6.2, dezembro de 2007. Disponível em: http://www.beatrizresende.com.br/questoesda-ficcao-brasileira-no-seculo-xxi/. Acesso em: 10 ago. 2016.

SANTANA, Jeová. Bazar de alucinações. [2003]. Disponível em: http://www.chicobuarque. com.br/critica/crit_budapeste_cialetras.htm. Acesso em: 10 ago. 2016.
SARAMAGO, Jeová. Autor cruza abismo e chega ao outro lado. [2003]. Disponível em: http://www.chicobuarque.com.br/critica/crit_budapeste_folha2.htm. Acesso em: 10 ago. 2016.

SCHØLLHAMMER, Karl Erik. Ficção brasileira contemporânea. Civilização Brasileira: 2010.

VERÍSSIMO, Luis Fernando. Luis Fernando Veríssimo: "escritor-fantasma". [2003]. Disponível em: http://www.chicobuarque.com.br/critica/crit_budapeste_globo1.htm. Acesso em: 10 ago. 2016.

WISNIK, José Miguel. Novo romance de Chico Buarque. [2003]. Disponível em: http:// www.chicobuarque.com.br/critica/crit_budapeste_wisnik.htm. Acesso em: 10 ago. 2016.

ANEXO

Figura 1 - Capa e contracapa de Budapeste (2003) pela editora Companhia das Letras.

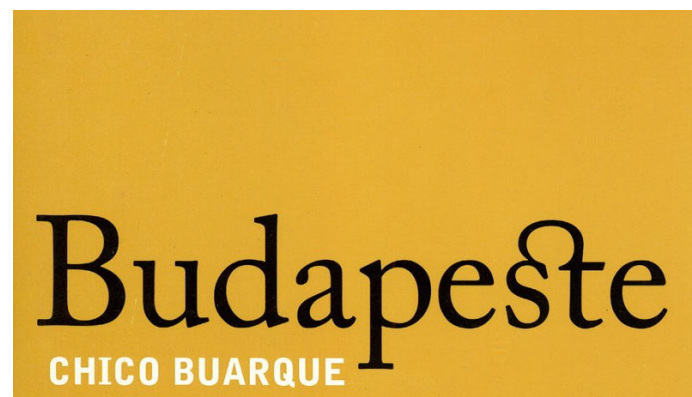

Fui dar em Budapeste graçs a um pouso imprevito, quando voova de Istmbul a Frankfurt, nexão para o Rio. A companhia ofereceu pernoite num hotel do aeroporto, e só de manhā nos informariam que o problema técnico, responsável por ima de bombe a ber No uma dencia anoralto o telejornal da meia-noite, eu, je me into por ao reconhecer o avião da companhia alemã parado na pista do aeroporto local. Aumentei o volume, mas a locução era em húngaro, única língua do mundo que, segundo as más línguas, o diabo respeita. Apaguit a teve, no Rio eram sete da noitc, tária elerrônim, tária eletrônica, não deixei recado, nem faria senti-
do dizer: oi, querida, sou eu, estou em Budapeste,
deu um bode no aviāo, um beeijo.

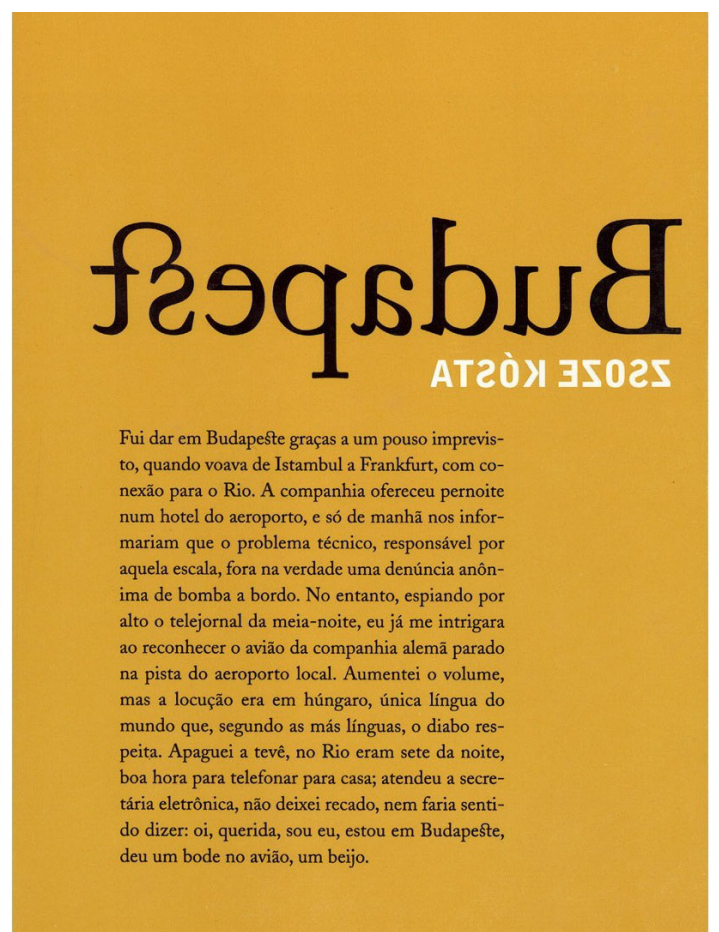

